\title{
Menilai Potensi Perang dibalik Kepemilikan Nuklir India dan Pakistan
}

\author{
Rayhana Fajria \\ Pascasarjana Ilmu Hubungan Internasional, Universitas Indonesia - Indonesia \\ Email: rayhana.fajria@ui.ac.id \\ Diserahkan: 13 August 2018 | Diterima: 26 November 2018
}

\begin{abstract}
India and Pakistan are two nuclear ownership that flank Kashmir. Claims against Kashmir territory and their history sparked long debate between countries. The conflict became one of the main roots of why India and Pakistan still continue to increase their nuclear power. Conflict continues to heat up creating such an arms race which makes both of them consider the existence of a potential big threat to their sovereignty. In analyzing the issue, this article examine the use of the deterrence theory, where this theory says there are several factors that are important conditions in seeing the possibility of nuclear war. Some of these factors are like; rational state as a condition of the nuclear launch command system, the two countries' abilities to develop second strike, and the India-Pakistan history of direct involvement in armed conflict.
\end{abstract}

Keywords: India, Pakistan, Nuclear, Deterrence, Military, War.

\begin{abstract}
Abstrak
India dan Pakistan adalah negara pemilik nuklir yang mengapit tanah Kashmir. Klaim atas tanah Kashmir beserta sejarahnya memicu perdebatan panjang bagi kedua negara tersebut. Konflik ini menjadi salah satu akar utama mengapa India dan Pakistan terus meningkatkan kekuatan militer hingga mengembangkan kepemilikan nuklir. Konflik terus memanas hingga menimbulkan perlombaan senjata yang membuat keduanya saling menganggap adanya potensi ancaman yang besar dan sewaktu-waktu dapat mengancam kedaulatan masing- masing negara. Sebelumnya pada April 2012 India telah melakukan percobaan rudal jarak jauh, dan tidak lama berselang diikuti oleh Pakistan yang meluncurkan rudal balistik berhulu ledak nuklir. Dalam menganalisa isu ini, penulis akan menggunakan teori deterrence, di mana teori ini mengatakan ada beberapa faktor yang menjadi syarat penting dalam melihat kemungkinan perang nuklir. Beberapa faktor tersebut seperti; rational state sebagai syarat sistem komando peluncuran nuklir, kemampuan kedua negara mengembangkan second strike, dan sejarah India-Pakistan tentang keterlibatan langsung mengenai konflik bersenjata.
\end{abstract}

Kata Kunci: India, Pakistan, Nuklir, Penangkalan, Military, War.

\section{PENDAHULUAN}

India dan Pakistan adalah dua negara yang terletak di kawasan Asia Selatan, di mana secara geografis keduanya adalah negara yang saling berdekatan dan berbatasan. Keduanya saat ini diketahui sedang mengembangkan senjata nuklir dan terus dalam keadaan perlombaan senjata. Keberadaan nuklir yang dimiliki oleh dua negara tersebut menimbulkan banyak sekali perdebatan dan pertanyaan. Salah satunya, apakah mungkin suatu saat keduanya akan mengalami perang nuklir? Dalam menjawab permasalahan tersebut, penulis akan 
menilai faktor-faktor apa sajakah yang dapat menentukan kemungkinan terjadi atau tidaknya perang nuklir melalui teori deterrence oleh Robert J. Art (2009).

Teori deterrence menjelaskan ada banyak persyaratan yang dimiliki oleh suatu negara yang memiliki nuklir untuk dapat menerapkan deterensi atau penangkalan (Art, 2009). Beberapa di antara syarat-syarat tersebut akan penulis angkat sebagai variabel-variabel yang dijadikan acuan dalam melihat kemungkinan terjadinya perang di antara India dan Pakistan. Variabel-variabel tersebut seperti: 1) teori deterrence memandang rational state adalah syarat yang harus diterapkan suatu negara dalam melakukan penangkalan. Hal ini guna menghindari adanya penyalahgunaan wewenang yang berkaitan dengan sistem komando peluncuran senjata nuklir, 2) tiap negara harus memiliki kemampuan second strike berupa kekuatan angkatan udara, darat, dan laut, yang semuanya memiliki kemampuan meluncurkan senjata nuklir, 3) sejarah masing-masing negara harus menunjukkan tidak adanya keterlibatan konflik bersenjata secara langsung sebagai faktor yang menjelaskan kecilnya keputusan konflik.

Dalam melakukan penulisan ini, penulis akan membatasi topik ke dalam ruang lingkup penelitian tertentu dengan tujuan agar lebih berfokus dalam menjawab research question yang akan diajukan. Variabelvariabel yang ditawarkan Robert J. Art mengenai teori deterrence begitu banyak dan penulis merangkumnya ke dalam tiga aspek utama untuk melihat kemungkinan terjadi atau tidak-nya perang nuklir di antara India dan Pakistan. Seperti yang telah dijelaskan sebelumnya, penulis hanya mengambil variabel berikut: 1) rational state, 2) kemampuan second strike, serta 3) sejarah keterlibatan konflik bersenjata secara langsung.

Penelitian ini bertujuan untuk mengetahui bagaimanakah pengaruh dari kepemilikan nuklir oleh India dan Pakistan terhadap perkembangan sistem dan hubungan di antara kedua negara tersebut. Dengan melihat kemungkinan-kemungkinan apa sajakah yang menjadi faktor penentu terjadi atau tidak-nya perang nuklir di antara India dan Pakistan, dan ini dirasa penting oleh penulis karena sampai saat ini persoalan kompleks di antara keduanya masih belum menemukan titik temu penyelesaian. Selain itu, penelitian ini juga bertujuan sebagai suatu wadah bagi penulis dalam membuktikan teori-teori yang berkembang, salah satunya deterrence. Walaupun kedua negara tersebut memiliki nuklir dan bisa saja berpotensi terjadinya perang, dapat dilihat bahwa hingga saat ini keduanya 
masih bertahan pada posisi masingmasing dan tidak melakukan penyerangan nuklir terhadap satu sama lain. Hal inilah yang menjadikan penulis merasa perlu untuk mencoba membuktikan penjelasan-penjelasan yang diberikan oleh teori deterrence.

Dengan melihat variabel-variabel apa saja yang perlu diteliti, serta latar belakang permasalahan antara India dan Pakistan, maka penulis akan mencoba menjawab pertanyaan berikut: Bagaimanakah melihat kemungkinan terjadi atau tidak-nya perang nuklir di antara India dan Pakistan?.

\section{TEORI DETTERENCE}

Robert J. Art (2009) menuangkan pemikirannya mengenai fungsi kekuatan bersenjata ke dalam tulisan yang berjudul The Use of Force dalam buku yang berjudul International Politics oleh Robert J. Art dan Robert Jervis yang di dalamnya menyebutkan salah satu kegunaan kepemilikan nuklir suatu negara sebagai penangkalan serangan dari negara lain. Penangkalan yang disebutkan oleh Art dikenal sebagai teori deterrence. MenurutRobert J. Art, dalam upaya penangkalan serangan, suatu negara harus memiliki strategi untuk mencegah terjadinya perang dengan cara mengecilkan hati lawan, yaitu menunjukkan ancaman atau kekuatan yang kita miliki dengan tujuan akan menimbulkan kerugian yang sangat besar melebihi keuntungan yang diharapkan jika negara oposisi bersikeras melakukan penyerangan (Art, 2009).

Menurut Art (2009), mengatakan bahwa:

"...The deterrent use of force is the deployment of military power so as toable to prevent and adversary from doing something that one does not want him to do and that he might otherwise be tempted to do by threatening him with unacceptable punishment if he does it. Deterrence is thus the threat of retaliation. Its purpose is to prevent sometbing undesirable from happening."

(Terjemahan lepas)

"...Penggunaan kekuatan jeralpenangkalan merupakan suatu penyebaran kekuatan militer agar mampu mencegah musub dari melakukan sesuatu yang tidak kita inginkan, atau hal yang dapat membuat mereka tergoda untuk melakukan hal tersebut, dengan mengancam negara tersebut melalui suatu bukuman yang keras jike dilanggar. Penangkalan ditujukan sebagai suatu ancaman pembalasan. Tujuannya adalah untuke mencegah terjadinya sesuatu yang tidak. diinginkan."

Dapat dijadikan suatu acuan, bahwa tujuan utama dari deterrence adalah untuk menangkal terjadinya suatu peperangan yang mengakibatkan kehancuran yang fatal. Sehingga, penyerangan balik atas penyerangan pertama bukanlah tujuan utama suatu negara yang men-deterensi negara lain 
dengan kekuatan senjata nuklir. Lebih lanjut, Art menjelaskan bahwa nuklir merupakan jenis senjata pemusnah massal yang dapat dijadikan alat untuk mendeterensi secara efisien. Akan tetapi, dengan adanya perlombaan senjata demi menangkal suatu serangan dapat menimbulkan security dilemma bagi masing-masing pihak yang terlibat (Art, 2009).

Selain Art, ilmuan politik lainnya yang ikut mewarnai teori-teori keseimbangan power dalam ilmu hubungan internasional adalah Patrick. M. Morgan, juga mengangkat istilah deterrence. Dalam bukunya yang berjudul Deterrence Now, ia menjelaskan bahwa deterrence adalah sebuah praktek lama dalam politik internasional. Konsep deterrence telah berkembang sejak lama yaitu pada era Perang Dingin - mencuat kepermukaan setelah Amerika Serikat menjatuhkan bom di atas Hiroshima dan Nagasaki. Morgan menerangkan bahwa deterrence itu sendiri adalah strategi militer dengan melakukan pencegahan dalam perang formal yang frontal melalui kepemilikan senjata pemusnah massal senjata nuklir (Morgan, 2003).

Kembali kepada pemikiran Art, yang menjelaskan bahwa dalam melakukan suatu deterensi/penangkalan, ada beberapa syarat tertentu yang harus dimilikioleh negara-negara tersebut (Art, 2009). Syarat-syarat tersebut akan dijadikan penulis sebagai variabel-variabel yang menentukan jawaban atas pertanyaan, apakah mungkin suatu saat India dan Pakistan mengalami perang nuklir? Atau, bagaimanakah melihat kemungkinan terjadi atau tidak-nya perang nuklir di antara keduanya? Dengan demikian, syarat-syarat yang di jelaskan oleh Art dirasa penting oleh penulis dalam menjelaskan permasalahan.

Syarat pertama yang akan penulis jelaskan adalah rational state. Negaranegara berlawanan yang memiliki nuklir demi mendeterensi satu sama lain haruslah memiliki sistem demokrasi sebagai suatu rasionalitas yang dimilikinya (Art, 2009). Mengapa? Karena sistem demokrasi mengharuskan pemerintahan dari suatu negara untuk mengadakan diskusi dan voting sebelum membuat suatu keputusan. Deterrence tidak membolehkan adanya pembuatan keputusan di tangan satu orang pemimpin, atau sistem otoriter. Karena, sistem otoriter tidak akan memberikan kebebasan bersuara seperti mengadakan perundingan. Maka dari itu, hal ini yang berupa sistem demokrasi bertujuan untuk mencegah terjadinya fatal decision (Morgan, 2003).

Syarat kedua adalah kemampuan suatu negara mengenai kapasitas second strike yang dimilikinya. Kemampuan second strike meliputi kekuatan angkatan 
darat yaitu nuclear land base, angkatan udara yaitu pesawat tempur yang dimungkinkan atau dapat mengangkut dan meluncurkan senjata nuklir, serta yang terakhir adalah angkatan laut yaitu kapal selam dengan kemampuan senjata nuklir (Morgan, 2003). Dengan kekuatan pada tiga aspek ini, diharapkan negara tersebut memiliki alat pembalasan yang dapat ditakuti jika negara lain memilih untuk melakukan penyerangan, dengan kata lain yaitu melakukan pencegahan dengan menunjukkan kemampuan yang dimiliki.

Setelah itu, syarat ketiga dalam teori deterrence adalah negara-negara yang bersangkutan tidak boleh sekalipun terlibat ke dalam konflik bersenjata secara langsung (Art, 2009). Keterlibatan masing-masing negara ke dalam konflik bersenjata secara langsung dapat menjadi faktor yang membuat keduanya mudah mengambil keputusan konflik yang kesekian kalinya di masa mendatang bagi kedua negara.

\section{OPERASIONALISASI TEORITIS}

Berdasarkan penjelasan mengenai teori deterrence tersebut, penulis akan mengkaji konsep operasionalisasi teori demi menjawab permasalahan yang telah diajukan. Berikut operasionalisasi teori kedalam bagan penyelesaian masalah:
Bagan 1: Indikator Syarat Terciptanya Deterensi

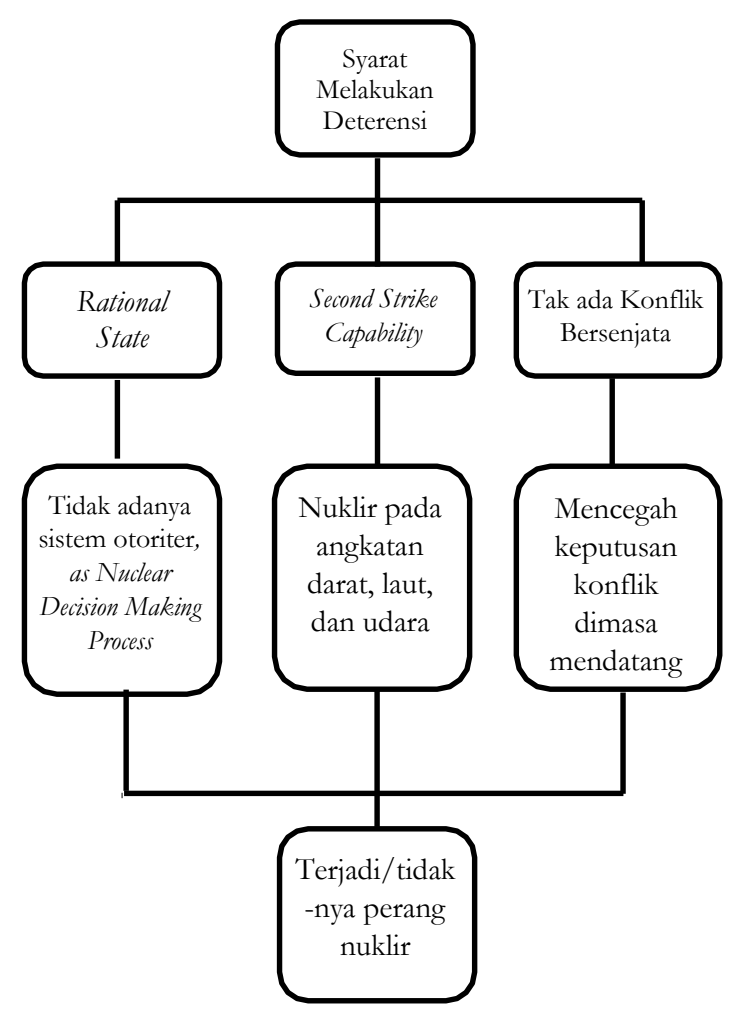

\section{SEJARAH PERSELISIHAN INDIA-PAKISTAN: KOMPLEKSITAS KONFLIK KASHMIR}

Hal yang disebut-sebut sebagai faktor yang melatar-belakangi perselisihan keduanya adalah permasalahan tanah Kashmir. Perselisihan keduanya mengenai Kashmir dikenal sebagai "konflik Kashmir". Konflik Kashmir berawal setelah India dan Pakistan merdeka dari tangan Inggris. India dan Pakistan diketahui merdeka pada tahun 1947. Keduanya mendapatkan kemerdekaan setelah Inggris meninggalkan kawasan. Akan tetapi, sesuai dengan partisi 562, menyatakan ada wilayah abu-abu yang diapit oleh kedua negara tersebut, yaitu 
wilayah Jammu dan Kashmir. Wilayah Jammu dan Kashmir juga mendapatkan kemerdekaan sepeninggal Inggris, kedua wilayah tersebut diberikan kebebasan untuk memilih akan bergabung ke salah satu negara yang ditetapkan - India dan Pakistan (Prasodjo, 2013).

Pilihan untuk bergabung didasarkan oleh suara terbanyak dari rakyat, yang notabene $70 \%$ dari total merupakan rakyat muslim dan sisanya adalah beragama hindu. Dengan fakta jumlah tersebut, Pakistan mengklaim bahwa Kashmir merupakan bagian dari Pakistan, serta sebaliknya India menilai bahwa Kashmir memiliki raja yang beragama Hindu dan Kashmir harus masuk menjadi wilayah India. (Johnson) Sejak saat inilah penulis menilai perselisihan antara India dan Pakistan mencuat. Hal ini dapat dinilai dari setidaknya, antara India dan Pakistan telah terjadi empat perang yang cukup hebat. Peperangan pertama yaitu pada tahun 1948, kemudian disusul pada tahun 1965, 1971, dan terakhir peperangan terjadi pada 1999 (The Carter Center Report, 2002). Perselisihan keduanya terus berlangsung dengan diiringi perlombaan kekuatan sejata dan pengembangan senjata nuklir. Hingga saat ini, hubungan bilateral kedua negara terus mengalami pasang surut diplomatik.

\section{PERSAINGAN KEKUATAN SENJATA NUKLIR INDIA- PAKISTAN}

Dalam

menjelaskan perkembangan senjata nuklir di antara India dan Pakistan, pertama-tama penulis akan menjelaskan perkembangan nuklir India dan diteruskan dengan Pakistan. Kebijakan penggunaan Nuklir India terbagi ke dalam tiga masa, yang pertama dimulai pada tahun 1947 hingga 1974. India pertama kali membuat kebijakan mengenai Nuklir saat pemerintahan Perdana Menteri Jawahahral Nehru. Kebijakan mengenai nuklir tersebut diartikulasikan dalam pidato PBB pada tahun 1953, yang pada saat itu kepemilikannya dibatasi dengan bertujuan sebagai sumber energiuntuk masyarakat. Disusul pada tahun 1955 dibantu oleh Kanada dan Amerika Serikat, India memulai program nuklir di Trombay. Tidak sampai di situ, tahun 1960 hingga 1961 dibangun pembangkit listrik bertenaga nuklir di Tarapur yang juga dibantu oleh Amerika Serikat. Bersamaan dengan ini, ratusan ilmuan India dilatih di banyak universitas dan laboratorium Amerika Serikat, sehingga pada tahun 1964 untuk pertama kalinya India memiliki senjata Plutonium (Cochran \& Norris). Pada tahun 1968 India menolak menandatangani Nuclear Non Proliferacy Treaty, serta terus mengembangkan nuklirnya untuk kepentingan militer yang hingga pada 
18 Mei 1974, India pertama kalinya menguji coba nuklir di wilayah Pokhran (Prasodjo, 2013).

Pada kebijakan tahap kedua yaitu pada tahun 1974 hingga 1998, secara teknis India sudah memiliki kemampuan untuk menciptakan senjata nuklir. Walaupun demikian, India tetap memiliki kebijakan dalam negeri untuk tidak memproduksi senjata nuklir jika tidak dalam keadaan terdesak. Namun, pada tahun 1980 hingga 1990 India tetap saja terus menyempurnakan desain-desain nuklimya, dan juga memodifikasi pesawat tempur yang dapat mengangkut rudal balistik berhulu ledak nuklir. Sejalan dengan kebijakan dalam negeri milik India, pada 11 Mei 1998 merupakan kali kedua India menguji coba nuklir (Prasodjo, 2013). Akan tetapi pada tahun 1999 India mengeluarkan pernyataan bahwa India tidak akan menjadi negara pertama yang menyerang dengan nuklir, kecuali untuk dijadikan serangan balasan jikalau suatu negara tertentu menyerang lebih dulu (Federation of American Scientists, t.t).

Jika India membangun kebijakan mengenai nuklir secara terbuka, hal ini berbeda dengan Pakistan, yang pada tahun 1972 memulai nuklir secara konsepsi serta diprakarsai oleh Zulfiqar Ali Bhutto. Pakistan mulai menyentuh konsep senjata nuklir setelah Pakistan Barat memisahkan diri menjadi Bangladesh. Sejak saat itu Pakistan membangun program dalam waktu yang dicanangkan selama 3 tahun. Program tersebut ikut dibantu oleh Cina dan Kanada, akan tetapi pada Desember 1976 Kanada menghentikan bantuan dan kerjasama program nuklir terhadap Pakistan dikarenakan Pakistan menolak menandatangani NPT dan IAEA kepada negara-negara pemilik nuklir (Federation of American Scientists). Walaupun begitu, Cina tetaplah menjadi negara penyokong terbanyak di akhir tahun 1970-an bagi Pakistan. Penulis melihat bahwa Cina memiliki peran yang sangat besar dalam perkembangan nuklir pakistan, dilihat dari berbagai bantuan yang diberikan seperti dalam proyek pengayaan uranium, memberikan bantuan bahan nuklir, bantuan teknis, desain hulu ledak, dan komponen sistem rudal lainnya. Akan tetapi program nuklir tersebut tidak hanya digunakan pada kepentingan dalam negeri semata, Pakistan diketahui melakukan transfer teknologi yang terbongkar di tahun 2004 kepada negera-negara seperti Libya, Iran, dan Korea Utara (The International Institute for Strategic Studies, 2007).

Demikianlah perkembangan senjata nuklir India dan Pakistan, yang masing-masing hingga saat ini terus melakukan penyeimbangan kekuatan. Beberapa hal yang membuktikan ini 
seperti saat India membuat kesepakatan nuklir bersama Amerika Serikat, Pakistan ikut membuat kerjasama nuklir dengan Cina sebagai bentuk kepentingan sipil di tahun 2000 dan 2010. Tidak hanya ini, terakhir pada April 2012 India telahmelakukan percobaan rudal jarak jauh, dan tidak lama berselang diikuti oleh Pakistan yang meluncurkan rudal balistik berhulu ledak nuklir. Hal ini diyakini penulis akan terus berlangsung dan masih sangat sedikit sumber yang penulis temukan mengatakan akhir dari perselisihan keduanya. Berdasarkan hal tersebut, penulis dapat menilai bahwa negara yang memulai tindakan balancing pertama kali adalah Pakistan. Balancing atau penyeimbangan power oleh Pakistan ini selalu direspon oleh India di mana keduanya terus menerus melakukan peningkatan militer terhadap satu sama lain, sehingga saat ini terciptal ah security dilemma yang belum memiliki ujungnya.

\section{MENILAI POTENSI TERJADI ATAU TIDAK-NYA PERANG NUKLIR}

Rational state sebagai indikator pertama dalam syarat terciptanya deterensi dapat dijelaskan dalam beberapa tahapan. Teori deterrence merupakan salah satu teori yang berkembang di Barat. Dengan kata lain, adalah hal yang sangat wajar, bagi para pengembang teori deterrence menjadikan demokrasi landasan rational state sebagai suatu syarat penting. Karena beberapa faktor perbedaan latar belakang tersebut, teori deterrence yang lahir dari dunia Barat tidak dapat diaplikasikan keseluruhannya kepada konflik antara India-Pakistan, namun peneliti masih dapat mengambil poin lainnya dalam deterrence untuk diaplikasikan dalam menganalisa konflik India-Pakistan. Penulis menganggap demokrasi tidak begitu menjadi bagian penting, hal yang lebih utama dalam rational state term adalah, suatu negara tidak boleh menerapkan sistem otoriter.

Deterrence menilai rational state adalah syarat penting dalam melakukan penangkalan - tidak adanya sistem otoriter. Karena hal tersebut mempengaruhi pengambilan keputusan mengenai peluncuran senjata nuklir. Yang artinya, penulis menilai bahwa hal ini menunjukkan keharusan suatu negara untuk menjadi rational state dalam melakukan suatu tindakan. India merupakan negara republik atau dikenal sebagai secutan republic of India. Bentuk sistem pemerintahan India yaitu demokrasi parlementer. Namun, dalam melihat hal tersebut, India dirasa oleh penulis telah memenuhi syarat suatu rational state. Sistem tersebut adalah dengan pemerintahan multi partai yang sangat kuat. Sedangkan Pakistan, dikarenakan 
mayoritas penduduk merupakan muslim, untuk itu Pakistan diberi nama republik Islam Pakistan. Akan tetapi Pakistan mulai mengadopsi sistem demokrasi parlementer pada 1956, di mana pemegang kekuasaan tertinggi yaitu perdana menteri sebagai kepala eksekutif, sekaligus kepala pemerintahan (Johnson). Dalam artian, penulis dapat mengambil kesimpulan bahwa kedua negara merupakan negara yang masuk ke dalam kategori rational state/actor. Kemampuan second strike sebagai indikator kedua, menjadi suatu poin penting dalam menilai kemungkinan konflik berkelanjutan atau perang di kemudian hari bagi kedua negara. Dalam menilai kemampuan serangan balik bagi keduanya, peneliti dapat melihat berdasarkan kekuatan angkatan darat, laut, dan udara, serta titik-titik lokasi pengembangan nuklir yang dimiliki oleh masing-masing negara. Hingga saat ini, peneliti menilai bahwa India lebih unggul dalam jumlah lokasi pengembangan nuklir dibandingkan Pakistan. India memiliki jumlah kawasan pengembangan nuklir yang lebih banyak. Pada gambar 3.1 dan 3.2. berikut ditunjukkan peta persebaran nuklir yang dimiliki oleh India dan Pakistan (Atomic Archive, 2014).
Gambar 1: Peta Lokasi Pengembangan Nuklir India

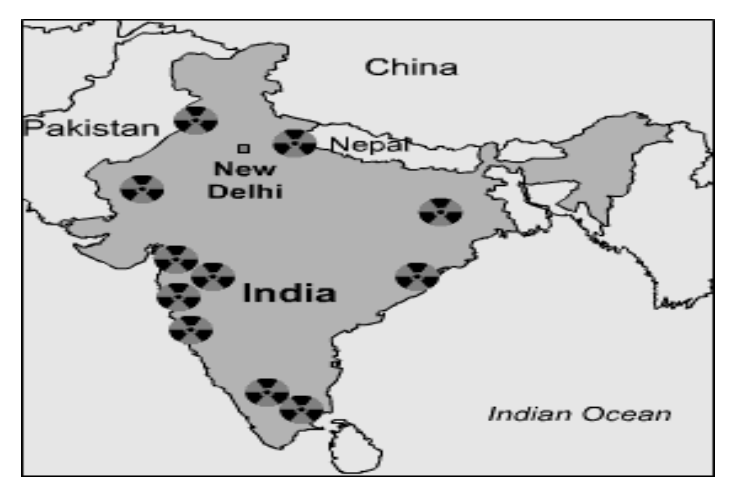

Gambar 2: Peta Lokasi Pengembangan Nuklir Pakistan

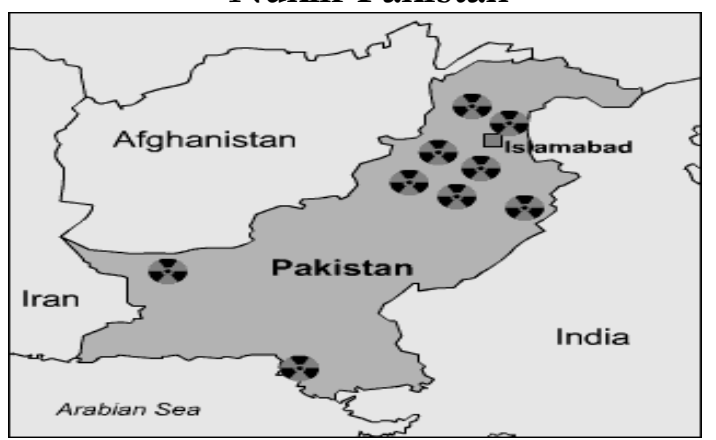

India saat ini sedang menjadi kekuatan militer udara yang paling besar bagi Asia Selatan dengan pesawat-pesawat udara canggih yang dimilikinya seperti pesawat tempurSu30 MKI, Mig-29, 27, 21, Jaguar, Mirage, C-17, C-130J, II-76, II-78, serta EMB-145 AWECS. Beberapa dari jenis pesawat canggih yang dimiliki oleh India tersebut adalah buatan asing yang di impor. Akan tetapi, dengan banyaknya jenis pesawat canggih yang dimilikinya, India tidak begitu baik pada sektor helikopternya. Pada improvisasi persenjataan sektor helikopter, India dapat dikatakan tidak begitu berkembang (Atomic Archive, 2014). 
Pada kekuatan lautnya, kapalkapal angkatan laut India juga sebagian besar merupakan kapal yang di impor dari asing. Sangat sedikit sumber yang penulis dapatkan mengenai produk asli yang mereka ciptakan. Kapal-kapal tersebut seperti kapal perusak Class pemburu dan $Q \& R$ Class dari Inggris, River Class dan Blackwood Class Frigat, Black Swan Class yang juga berasal dari Inggris. Kapal perang canggih lainnya juga dibeli oleh India dari Russia. Seiring dengan berjalannya waktu, India terus melakukan improvisasi dan meng-upgrade kapal perangnya, kekuatan angkatan laut India bangkit serta sekarang India memiliki kapal tercanggih di dunia (Atomic Archive, 2014).

Setelah perkembangan signifikan angkatan laut yang dimiliki India, hal ini cukup berbeda dengan kekuatan angkatan darat mereka. Perkembangan angkatan darat India sedikit terhambat dan tidak begitu banyak alat-alat canggih yang dapat mengangkut nuklir yang dimiliki oleh India. Akan tetapi, perusahaan pribumi menjadi sumber mayoritas yang melatarbelakangi kekuatan angkatan darat India, seperti bahan peledak, dan mortir yang sebagian besar dibuat oleh 41 - nama perusahaan pribumi. Akan tetapi alat lain seperti artileri, masih sebagian besar diimpor (Atomic Archive, 2014). Penulis menyadari, India melakukan banyak sekali impor pada kekuatan udara dan lautnya, akan tetapi seiring dengan berjalannya waktu, India terus berkembang. Perkembangan tersebut terlihat dari konsentrasi India pada pengembangan rudal independen.

Dibandingkan dengan India, Pakistan cenderung berbeda. Pakistan juga memiliki second-strike capability yang mumpuni, hanya saja, kapabilitas ini dapat dikatakan ada pada kekurangan yang dimiliki oleh India, begitu juga sebaliknya dengan kapabilitas India terhadap Pakistan. Pakistan juga menjadi pesaing yang ikut mengimpor pesawat tempur canggih, seperti dari rekannya, yaitu Cina. Dikutip dari perkataan pejabat senior pertahanan Pakistan, yang mengaku bahwa Pakistan telah mengakuisisi 30 sampai 40 jet tempur siluman FC-31 dari Cina untuk bisa mengimbangi kekuatan udara India. Dalam waktu dekat, juga dipastikan bahwa Pakistan akan membeli kekuatan udara tambahan yaitu pesawat canggih FC-31 yang diisukan dapat mengalahkan kekuatan F-16 milik Amerika Serikat (Atomic Archive, 2014).

Suatu data bersumber dari intelegen Amerika Serikat mengatakan bahwa Pakistan setidaknya saat ini mempunya 80 sampai 100 hulu ledak nuklir. Akan tetapi penulis menilai mungkin jumlah yang dimiliki lebih besar mengingat bahwa uranium bersama dengan pengayaannya dan plutonium di Pakistan adalah salah 
satu yang tercepat dalam kapasitas produksi. Namun angkatan laut Pakistan jauh lebih sedikit dibanding India, akan tetapi jumlah angkatan udara Pakistan diindikasikan memiliki jumlah yang lebih dibanding India (Atomic Archive, 2014). Sehingga, dari semua penjelasan di atas penulis dapat menarik kesimpulan bahwa India dan Pakistan berada dalam posisi yang saling mengejar dan terus mengimbangi.

Indikator analisis terakhir adalah sejarah keterlibatan konflik bersenjata secara langsung. Tidak bisa dipungkiri, walaupun teori deterrence mensyaratkan negara yang bersangkutan tidak pernah terlibat konflik bersenjata secara langsung, sejarah menjelaskan India dan Pakistan telah empat kali mengalami konflik bersenjata dalam rentang waktu yang dimulai pada tahun 1947 hingga tahun 1999. Dimulai pada tahun 1947 saat India mengirimkan pasukannya ke wilayah sengketa, mengetahui hal ini Pakistan membalas dengan mengirim pasukan dan perang pecah pada akhir tahun 1947 hingga tahun 1948. Menanggapi hal ini India meminta bantuan PBB, dan akhirnya PBB mengirimkan bantuan untuk me-monitoring wilayah kawasan yang bersengketa (National Defence and the Canadian Forces, 2008).

Akan tetapi, beberapa waktu setelahnya perang kedua pecah lagi pada tahun 1965. Perang kedua ini dimulai saat Pakistan mengirim 33.000 orang yang menyamar menggunakan pakaian mirip penduduk setempat menyerupai masyarakat Kashmir. Melihat hal ini India menanggapi dengan mengirimkan kurang-lebih berjumlah 600 tank sebagai respon negatif (National Defence and the Canadian Forces, 2008). Melihat panasnya perselisihan kedua kubu, dunia internasional mulai mengkhawatirkan peperangan tersebut, dan PBB turun tangan lagi dengan memberikan perintah atau mandat agar India dan Pakistan melakukan gencatan senjata (United Nation Military Observer Group in India and Pakistan).

Tidak berhenti pada tahun 1965, perang ketiga pecah pada tahun 1971 yang berlangsung selama 13 hari. Perang kali ini dikarenakan oleh Pakistan yang pertama kali menjatuhkan bom di lapangan terbang barat laut India, sehingga India melakukan serangan yang fatal dan menghasilkan kekalahan pada pihak Pakistan. Kekalahan pakistan diikuti dengan 90.000 orang yang dijadikan tawanan perang oleh India. Sejak saat itu, Pakistan terbelah menjadi dua, dan bagian yang memisahkan diri menjadi Bangladesh (Paracha, 2014). Setelah masa-masa tersebut, hubungan India dan Pakistan diwarnai oleh perjanjianperjanjian - Line of Control Treaty untuk 
menghormati batas yang sudah disepakati dan Simla Accord yang berisikan perencanaan perdamaian yang menurut penulis tidak begitu menyelesaikan permasalahan di antara keduanya (Chari \& Kargil, 1999).

Hingga pada tahun 1999, konflik bersenjata secara langsung kembali terulang. Pakistan memulai kudeta lagi dan peperangan kali ini dinamakan perang Kargil. Melihat kondisi konflik yang tiada henti-hentinya, pada 2001 kedua belah pihak mengadakan pertemuan akan tetapi menemui jalan buntu dan tidak mendapatkan hasil apa-apa. Pada tahun 2002 India dan Pakistan mengalami sedikit pencerahan saat dunia internasional bersedia memediasi keduanya. Seiring dengan berjalannya waktu, keduanya sedikit demi sedikit menarik pasukan dalam jumlah yang bertahap. Hingga pada 2004 keduanya kembali mengadakan dialog antara pejabatpejabat negara. Diteruskan pada 2007 keduanya mengadakan dialog kembali yang membicarakan rudal nuklir balistik dan kapabilitas nuklir masingmasing (Prasodjo, 2013). Akan tetapi pada 2012 India menguji coba rudal jarak jauh, dan tidak lama berselang Pakistan ikut menguji coba rudal balistik berhulu ledak nuklir. Dalam rentang waktu tahun 1999 hingga saat ini, kerjasama dan perselisihan tetap saja diwarnai percekcokan dan konflik di perbatasan, dan dari pihak-pihak separatis lainnya. Hingga saat ini, tahun 2016 pun hubungan bilateral keduanya terus mengalami pasang surut.

Seiring dengan pasang surut hubungan keduanya, penulis melihat bahwa pemerintah dari kedua belah pihak hingga saat ini terus melaksanakan hubungan yang baik. Konflik-konflik dan hal lainnya yang memicu perselisihan acapkali datang dari pihak-pihak separatis, namun tidak pernah mengakibatkan perang bersenjata yang keputusannya datang langsung dari pemerintah atau pemimpin keduanya. Dengan demikian, penulis menilai bahwa hubungan keduanya semakinmembaik dari waktu ke waktu.

\section{KESIMPULAN}

Kesimpulan yang dapat penulis tarik dari penelitian di atas adalah kemungkinan perang nuklir di antara keduanya kecil. Hal ini dikarenakan hampir seluruh persyaratan berdasarkan teori deterrence ada pada dua negara tersebut. Pecahnya perang nuklir dirasa akan sangat sulit untuk terjadi pada keduanya. Hal ini juga dilatarbelakangi dengan hubungan India-Pakistan yang semakin membaik dan dinamis. Jika menilai kemungkinan perang berdasarkan teori deterrence adalah kecil, penulis tetap menganggap bahwa kemungkinan tersebut masih ada dan 
tidak dapat diprediksi dengan sangat akurat. Penulis berpendapat bahwa satu-satunya jalan keluar dari perselisihan dengan menjadikan lembaga raksasa internasional untuk memediasi keduanya dengan menciptakan hubungan-hubungan melalui berbagai kerjasama sehingga diharapkan dapat meredam perselisihan.

\section{DAFTAR PUSTAKA}

Art, R. J. (2009) The Political Use of Force: The Four Function of Force dalam R. Art, \& R. Jervis, International Politics: Enduring Concepts and Contemporary Issues, 9th ed, New York: Pearson Education, hlm. 132-138.

Cochran, T. B., \& Norris, R. S. (2013) Nuclear Weapon (Online). Tersedia di: https://www.britannica.com/technol ogy/nuclear-weapon (Diakses: 21 November 2016).

Federation of American Scientists. (2014) Strategic Security Project: India Nuclear Weapons (Online)Tersedia di: http://fas.org/nuke/guide/india/nuk e/ (Diakses: 21 November 2016).

Federation of American Scientists. (2014) Strategic Security Project: Pakistan Nuclear Weapons (Online). Tersedia di: http://fas.org/nuke/guide/pakistan/ nuke/ (Diakses: 21 November 2016).
Johnson, D. (t.t.) India-Pakistan Relations 50 Years History (Online). Tersedia di: http:/ / asiasociety.org/education/indi a-pakistan-relations-50-year-history (Diakses: 20 November 2016).

Morgan, P. M. (2003) Deterrence Now. Cambridge: Cambridge University Press. Hlm. 1-41.

National Defence and the Canadian Forces. (2008) Details/Information for Canadian Forces (CF) Operation United Nations Commission for India and Pakistan (Online). Tersedia di: http://www.cmpcpm.forces.gc.ca/dhh-dhp/od$\mathrm{bdo} /$ di-rieng.asp?IntlOpId $=263 \& \mathrm{CdnOpId}=3$ 11 (Diakses: 21 November 2016).

Paracha, N. F. (2014) Indo-Pakistan Relations Saazish and Saalan. Monthly Journal of Realism, hlm. 50-62.

Prasodjo, H., 2013. Perlombaan Senjata Nuklir di Asia Selatan antara India dan Pakistan . Jurnal Sistem Keamanan Internasional, hlm. 4-21.

The Carter Center. (2002) The Kashmiri Conflict: Historical and Prospective Analysis. The Carter Center Report, hlm. 1-16.

United Nation Military Observer Group in India and Pakistan. (t.t) UNMOGIP Background (Online). Tersedia di: http://www.un.org/en/peacekeeping /missions/unmogip/background.sht ml (Diakses: 21 November 2016). 